\title{
Asiatic \\ Pennywort \\ [Centella asiatica \\ (L.) Urb.]: A \\ Little-known \\ Vegetable Crop
}

\author{
K.H.S. Peiris and S.J. Kays ${ }^{1}$
}

Addtional index words. specialty vegetables, culture, photochemistry, medicinal herb

Summary. Centella asiatica, the Asiatic pennywort, is an herbaceous perennial indigenous to the southeastern United States. In some Asian countries, it is valued as an important vegetable and is widely cultivated. In addition, it is considered an important medicinal herb due primarily to the pentacyclic phytochemical, asiaticoside, which effectively treats a variety of skin diseases. Information on the botany, photochemistry, medicinal, nutritional value, and cultivation of the crop is reviewed. This species may warrant preliminary field and consumer acceptance tests as a speciality vegetable in the United States.

$\mathrm{V}$ egetables make up a major portion of the diet of humans. An increased awareness of the health advantages of diets high in vegetables has been a significant stimulant in increasing consumption. In addition, there has been a significant increase in the number of vegetable crops available to consumers in the United States over the past 15 years. Increasing ethnic diversity within many areas of the United States has stimulated the introduction of new crops. For example, tindora [Coccinia grandis (L.) Voigt. ] and parval ( Trichosanthes dioica Roxb.), two littleknown vegetables in the United States,

Department of Horticulture, University of Georgia, Athens, GA .30602-7273.

The cost of publishing this paper was defrayed in part by the payment of page charges. Under postal regulations, this paper therefore must be hereby marked advertisement solely to indicate this fact. 
can now be found in ethnic markets (Kays and Dias, 1995). Centella asiatica, the Asiatic pennywort (Fig. 1), represents another potentially new commercial vegetable. Although indigenous to the southeastern United States, the Asiatic pennywort is of considerable importance in Bangladesh, Thailand, Madagascar, Malaysia, Indonesia, and Sri Lanka (Bagchi and Puri, 1989; Bautista et al., 1988; Rasoanaiva, 1990). It is one of the major leafy vegetables grown in Sri Lanka, prized for its aromatic and slightly pungent flavor, and is available in markets year round. The Asiatic pennywort has long been used in the East for its pharmacological properties, reputed to confer a wide range of beneficial effects (Lesley, 1994; Turton, 1993), and was treated as a valuable medicinal plant in classical Indian Ayurvedic medicine, as evidenced by 11 Sanskrit names for the plant (Jayaweera, 1982). The following report critiques the horticultural, phytochemical, and medical information available on the crop.

\section{Nomenclature}

The Asiatic pennywort is also known as the Indian pennywort, marsh pennywort, water pennywort, pennyweed, and, occasionally, sheep rot. Asiatic pennywort has the following names in other languages: hahanghalo (Cebuano); ji xue cao, luei gong gen, tung chain (Chinese); asiatisk centella (Danish); ecuelle d'eau, hydrocotyle asiatique (French); Indischer Wassernabel (German); braham-manduki, khulakhudi, valari (Hindi); daun kaki, kuda (Indonesia); yahon-yahon (Ilongo); idrocotile (Italian); gotukola, tsubo-kusa (Japanese); pegaga (Malay): cairussd, donheiro em penca, pata de cavalo (Portuguese); mandukaparni (Sanskrit); gotukola (Sinhala); hierba de clavo (Spanish); takip-kohol, thakipsuso (Tagalog); and vallarai (Tamil).

Several botanical synonyms for Asiatic pennywort are listed in the literature: Hydrocotyle asiatica L.; $H$. wightania Wall.; $H$. lurida Hance.; $H$. nummularioides Rich.; and $H$. pallida DC. The earlier classification as $H$. asiatica L. was subsequently corrected to Centella asiatica (Bagchi and Puri, 1988). Centella differs from Hydrocotyle in leaf, flower and fruit characteristics. In Hydrocotyle, the two mericarps have three ridges each, the flowers are white, the pericarp and seed are thin, and the leaves are lobbed, while in Centella the two mericarps possess seven to nine ridges each, the flowers are red or purple, the pericarp is thick, and the leaves are unlobbed.

Centella is comprised of about 20 species, found mainly in South Africa (Mabberley, 1987), belonging to the family Apiaceae (also known as Umbelliferae). Centella asiatica is a perennial herb with long slender horizontal stolons, characterized by long internodes, from which arise a cluster of ascending petiolate leaves at each node (Fig. 1). Leaf size and margins vary; the latter can be smooth, crenate, or slightly lobed. Inflorescences of one to four simple umbels per node contain one to four flowers per umbel and form throughout the growing season. The petals are white, often tinged with rose; the calyx teeth are obsolete; the fruit are ellipsoid, 3 to $4 \mathrm{~mm}$ long, and 3 to $5 \mathrm{~mm}$ broad (broader than long) (Correll and Correll, 1982).

\section{Ecology}

Centella asiatica grows wild under a wide range of climatic condi-

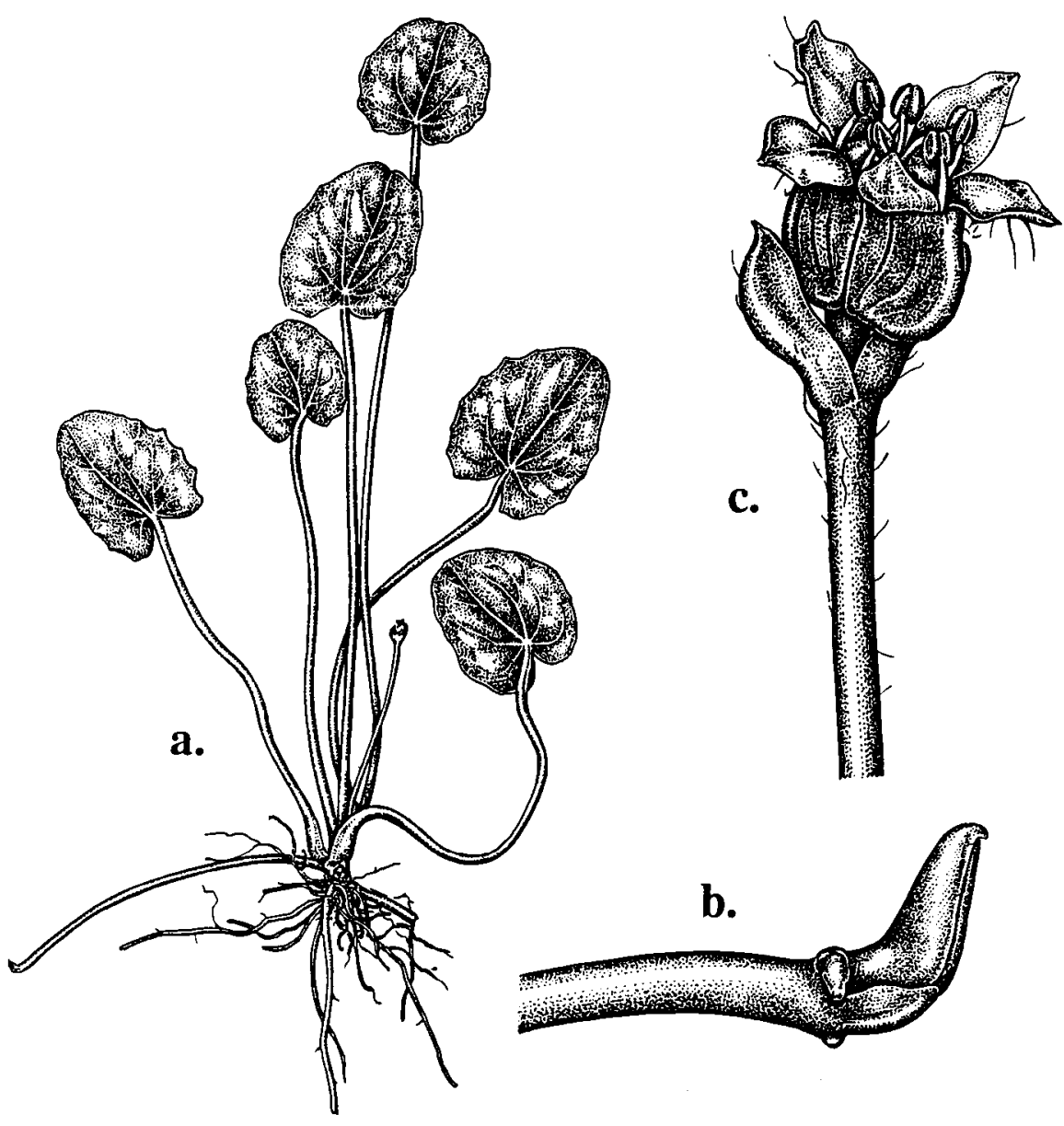

tions, but is more abundant in secondary-succession communities (Wankar and Tripathi, 1990b, 1993). In the wild, the plant is found in wet or moist soils of marshes, bogs, and swamps and along the margins of lakes, ponds, streams, irrigation and drainage canals, and bunts of irrigated paddy fields. It is also found in wet pine savannas, flatwoods, and palmetto flats, often forming meadows. It grows in water and on land. The species is pantropic, found in the United States from Delaware to southern Florida and west into Texas, in the West Indies, Mexico, Central and South America, Australia, India, Sri Lanka, New Caledonia, Philippines, China, Indonesia, Malaysia, Madagascar, Sikkim, and other tropical and subtropical regions of the world (Bagchi and Puri, 1988; Correll and Correll, 1982; Correll and Johnston, 1970; Godfrey and Wooten, 1981; Grieve, 1971; Jayaweera, 1982;

Fig. 1. Centella asiatica: (a) general morphology of the plant; (b) growing point of a stolon; and (c) flower (Correll and Correll, 1982). 
Mandal, 1992; Turton, 1993).

Preferred natural habitats for Asiatic pennywort are moist locations from sea level to higher elevations; for example, in the Himalayas it can be found growing up to $700 \mathrm{~m}$ (Bagchi and Puri, 1988). Populations growing in different habitats show marked variation in dry-matter yield, stolon production; leaf area, petiole length, and other traits (Wankhar and Tripathi, 1990a). The plant relies primarily on vegetative reproduction rather than seed, although seeds are formed. Plants derived from cuttings are more competitive than those developing from the seeds (Wankhar and Tripathi, 1990b).

\section{Cytology}

Most cytological studies on $C$. asiatica indicate the somatic chromosome number of $2 \mathrm{n}=18$ forming regular nine bivalents (Bell and Constance, 1960; Sharma and Ghosh, 1954; Singha and Singha, 1977; Subramanian, 1986). The reported chromosome number varies (e.g., $2 \mathrm{n}$ $=22$ for plants from Lucnow, $2 \mathrm{n}=18$ in plants found in Bengal), suggesting an existence of chromosomal races within the species (Bagchi and Puri, 1988).

Certain plants possess accessory or B-chromosomes, small chromosomes present in addition to the normal compliment of stable or A-chro-

Fig. 2. A commercial field of Centella asiatica in Sri Lanka. mosomes (Sinha and Sinha, 1977). The accessory chromosomes are quite small, dot shaped, and euchromatic. During meiosis, the B-chromosomes possess only ring and rod bivalents varying from 6-11 and $0-5$ respectively, with univalent absent. One to two B-chromosomes were found in $73 \%$ of pollen mother cells. The two accessories present in the same cell do not pair to form bivalents at metaphase; however, during first mitotic division they divide to form four chromosomes. The accessory chromosomes arise from A-chromosomes through chromosomal aberrations, hybridization, aneuploidy, and changes in chromosomal number during speciation. Plants possessing B-chromosomes are morphologically indistinguishable from normal plants (Joshi and Raghuvanshi, 1970).

\section{Culture}

Although the plant grows readily in full sun, most commercial plantings in Sri Lanka are in partially shaded, moist locations. Shade is prefered in that the plants develop a profuse canopy of leaves with long petioles (Fig. 2). While high light intensity produces more leaves and clonal offspring and a greater leaf area and dry matter, low light regimes are considered superior for the erect types producing substantially longer petioles (Wankar and Thipathi (1990b). If grown in full sun, another cultivar that has a more creeping habit but longer petioles is commonly selected.

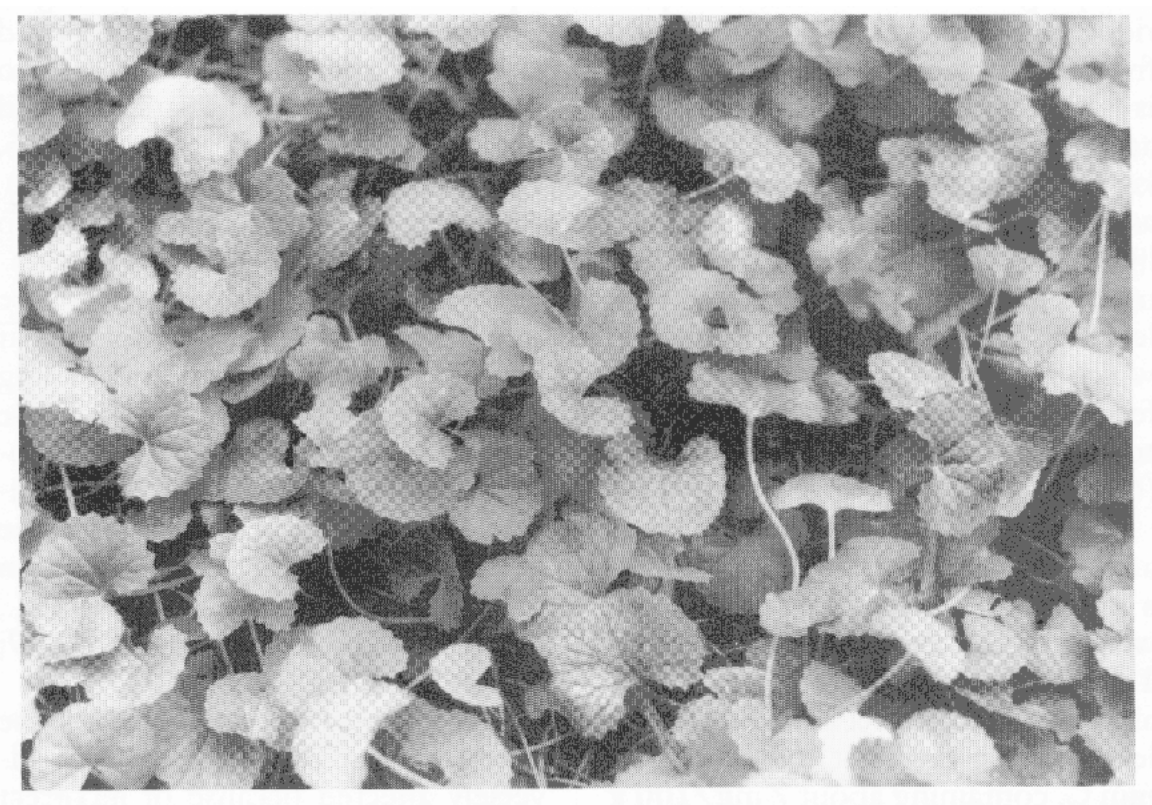

Growth is favored by sandy loam soils high in organic matter and a high soil moisture regime, especially under high light intensity. The land is prepared by plowing to a depth of about $20 \mathrm{~cm}$ and producing a good friable soil condition. Sunken beds are preferred to facilitate high moisture conditions. Organic materials such as cow manure or leaf compost are added at planting and about every 6 months thereafter at the rate of $1.5 \mathrm{~kg} \cdot \mathrm{m}^{-2}$. Apart from organic manures, fertilizers are rarely applied, except for relatively small amounts of urea, which is periodically added to facilitate leaf growth. Precise fertilizer recommendations are not currently available, although fertility experiments are in progress in Sri Lanka (Anonymous, 1990).

There are two general cultivars of Asiatic pennywort commercially grown in Sri Lanka: a small-leaved creeping form and a large-leaved erect bush form (Anonymous, 1978, 1990), with lines that have been selected within each of the two types. For commercial plantings, propagation is exclusively via asexual means, using pieces of runners. Planting material is prepared by cutting stem pieces having one node. The bush type is planted at a $30 \times 25$ $\mathrm{cm}$ spacing, while the creeping type is planted at a closer spacing $(15 \times 15$ $\mathrm{cm})$ due to its slower growth rate. Partial shade may be beneficial for the vigorous growth of the crop but not essential. For both types, adequate soil moisture is required for initial establishment and subsequent growth.

If moisture is not limiting, the first harvest can be in about 90 days from planting. Subsequent harvests are often at 60-day intervals. A planting can be harvested more or less continually over 2 to 3 years in Sri Lanka. The plants are harvested when the leaves reach full size. Harvest should not be delayed because leaf quality tends to decline. Bush types yield $8 \mathrm{t} \cdot \mathrm{ha}^{-1}$ at the first harvest and 14 thha ${ }^{-1}$ at subsequent harvests. Yield data for creeping types are not available; however, yields are generally considered lower in that the plants are slower growing and have smaller leaves with shorter petioles. The manner of harvesting creeping type is not conducive to multiple harvests.

In Sri Lanka, the creeping type has a more limited market. whole plants are uprooted and bundled with their roots for marketing (Fig. 3a). The 


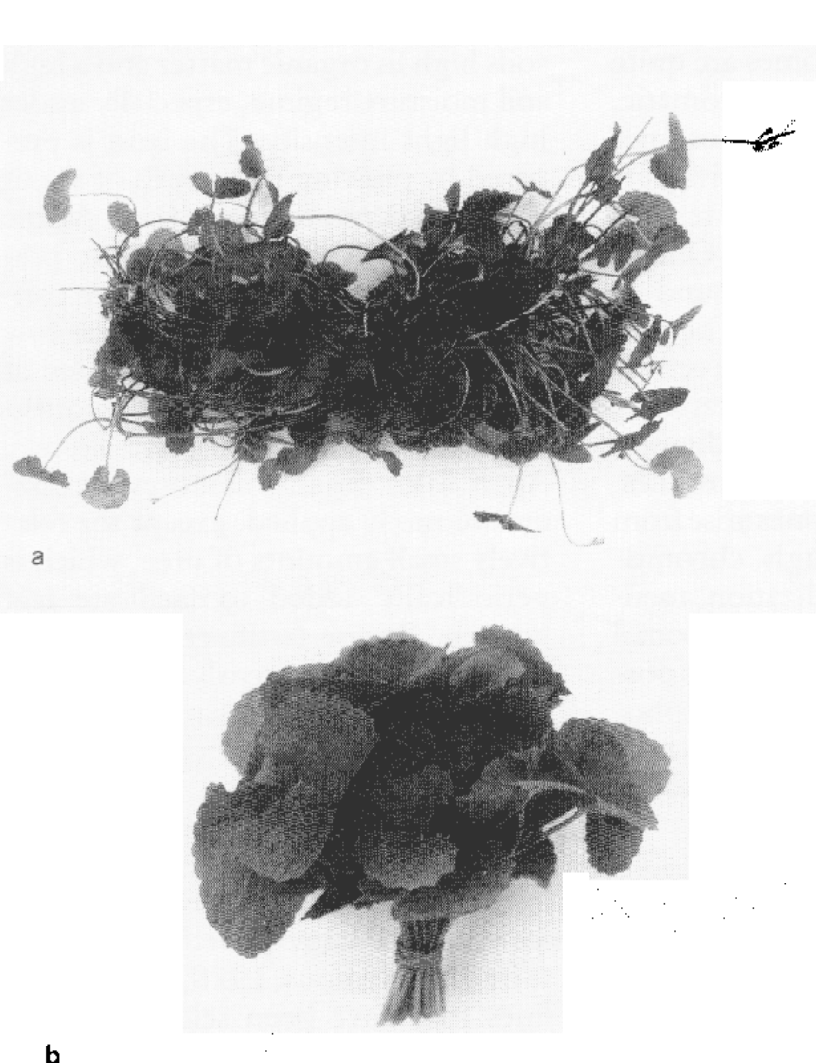

b

Fig. 3. Centella asistica is typically marketed as a vegetable in Sri Lanka in small bundles. The creeping types (a) are tied in loose bundles while the more common erect types $(b)$ have the individual petioles gathered and tied at the base.

erect type has long petioles that are cut at the base and bound using sting or straw in about 1-inch-diameter bundles for marketing (Fig. 3b). The bundles are packed in bamboo baskets or woven polyethylene bags for transportation. Due to the lack of refrigeration, the leaves must be sold within 2 to 3 days after harvesting. In Sri Lanka, most commercial production sites are near major city centers. Fields are scheduled such that sufficient area can be harvested daily to supply market requirements. Thus, the time interval between harvest and consumption is relatively short, minimizing postharvest losses. Postharvest treatments are limited to those minimizing water loss, such as applying water sprays during the day when the product is sold in open areas.

The Asiatic pennywort has few reported pest and disease problems under intensive commercial cultivation. A bacterial wilt caused by Pseudomonassolanacearum Smith has been recently reported in Sri Lanka (Zoysa and Liyanage, 1994). As a weed growing in cultivated lands, the Asiatic pennywort is suggested as an alternative host for some pathogens, although disease symptoms do not develop in the host. The epiphytic occurrence of Xanthomonas campestris pv. campestris, which causes a black rot in many of the cultivated cruciferae, has been reported by Kishun and Chand (1988). Bagchi and Puri (1988) have indicated that $X$. campestris f.sp. centellae f.sp. nov. causes leaf spot symptoms.

\section{Culinary uses and nutritional value}

Several food preparations are made from the Asiatic pennywort in Sri Lanka. It is most commonly used as a green salad vegetable. Finely sliced leaves are mixed with sliced shallot, green chillies, and lime juice and salt are added. It is also cooked as a curry with spices, onion, and coconut milk. Creeping cultivars are used for a porridge preparation. Fresh juice pressed from whole plants, including the roots, is boiled with a small amount of rice and coconut milk to prepare 'gotukola kenda', a thin porridge commonly used as a breakfast drink. Centella asiatica is likewise one of the most commonly used and frequently available edible leaves used in leaf concentrate meals, which are prepared as a porridge for feeding preschool children in Sri Lanka to combat nutritional deficiencies (Cox, 1993).

Leaves of the Asiatic pennywort are $87.7 \%$ moisture and $2 \%$ protein on a fresh weight basis $(16.26 \%$ dry weight), $0.2 \%$ fat, $6.7 \%$ carbohydrate, $1.6 \%$ fiber, and $1.6 \%$ ash (Bautista et al., 1988; Zanariah et al, 1986). Fresh leaves are an excellent source of vitamin $\mathrm{C}$, containing about $7 \mathrm{mg} / 100 \mathrm{~g}$
(Gunasekara and Ravindran, 1989) and contain 738 IU of vitamin A and 0.09 $\mathrm{mg}$ of vitamin B 1/100 $\mathrm{g}$ fresh edible material (Bautista et al., 1988). When the leaves are allowed to wilt, however, $95 \%$ to $99 \%$ of the vitamin C is lost (Kailasapathy and Koneshan, 1986). The plant is also a relatively good source of the minerals $\mathrm{Ca}(171 \mathrm{mg} /$ $100 \mathrm{~g}$ edible), $\mathrm{P}$ (32), and $\mathrm{Fe}$ (5.6) (Bautista et al., 1988; Jayaweera, 1982; Turton, 1993). Leaf composition varies somewhat with location.

\section{Photochemistry}

Based on its long-standing medical use, many phytochemical studies have been conducted on $C$. asiatica (see reviews by Kartnig, 1988, and Turton, 1993). In 1938, a triterpenoid glucoside, asiaticoside (Fig. 4), isolated from the plant was effective in the treatment of leprosy (Anonymous, 1945 b). Initial chemical characterization of the triterpenoid fraction, thought to comprise the primary biologically active components, followed (Bhattacharyya and Lythgoe, 1949; Boiteau et al., 1949; Lythgoe and Trippett, 1949). The total triterpenoid content is often quoted to range from $1.1 \%$ to $8.0 \%$ of the leaf dry weight (Rao and Seshadri, 1969); however, these figures represent the total nbutanol extracts of undefined plant samples and most probably over estimate the actual level. Using more recent data by Das and Mallick (1991) and assuming asiaticoside to comprise $40 \%$ of the total triterpenoid fraction, the mean triterpenoid fraction would equal $0.1765 \%$ of the leaf dry weight. The terpeniod fraction is comprised largely of the sugar esters of two pentacyclic terpenoids, asiaticoside and madecassoside, and their aglycones, asiatic and madecassic acids (Fig. 4). The three subunit glucoside sidechain in asiaticoside and madecassoside consists of one rhamnose and two glucose molecules. Other triterpenoids that may or may not be present, depending on the plant source, include centelloside, brahmoside, brahminoside, thankuniside, and isothankuniside. (For additional details on the chemistry of the triterpenoid fraction see Karrer et al., 1985; Kartnig et al., 1987; Lythgoe and Trippett, 1949; Rahandraha et al., 1963a, 1963b.)

The literature, on the triterpene chemistry of $C$. asiatica has been adversely affected because of incorrect 
<smiles>[R]C(=O)C12CCC(C)C(C)C1C1=CCC3C4(C)CC(O)C(O)C(C)(CO)C4C([R])CC3(C)C1(C)CC2</smiles>

$\begin{array}{lll}\text { Compound } & \underline{\mathrm{R}}_{1} & \underline{\mathrm{R}}_{2} \\ \text { Asiatic acid } & -\mathrm{H} & -\mathrm{OH} \\ \text { Madecassic acid } & -\mathrm{OH} & -\mathrm{OH} \\ \text { Asiaticoside } & -\mathrm{H} & \text {-O-glu-glu-rha } \\ \text { Madecassoside } & -\mathrm{OH} & \text {-O-glu-glu-rha }\end{array}$

Fig. 4. Structure of the primary pentacyclic triterpenoids from Centella asiatica.

nomenclature and different ecotypes of the plant have been described. The content and composition of the triterpene fraction varies among ecotypes collected from different regions of the world. For example, the main triterpenes found in plants from Madagascar are asiaticoside and madecassoside, while in those from Sri Lanka are centelloside (Kartnig 1988; Lythgoe and Trippett, 1949). Indian ecotypes contain brahmoside, brahminoside, asiaticoside, thankuniside, and isothankuniside (Kartnig, 1988). Das and Mallick (1991) have reported that asiaticoside content varies with genomic diversity. Higher levels of asiaticoside were isolated in plants collected from subtemperate areas in the Himalayas and those containing two B-chromosomes. In Madagascar samples, asiaticoside made up $40 \%$ of the total triterpenoid component (Turton, 1993).

In addition to the terpenoid fraction, a broad cross-section of other phytochemicals have been identified in $C$. asiatica. These include sugars (Bhattacharyya, 1956a, 1956b; Malhotra et al., 1961; Singh and Rastogi, 1968), fatty oils (Wali and Katti, 1937), amino acids (George and Gnanarethinam, 1975; Malhotra et al., 1961), vellarin (Chopra et al., 1969; 1956), polyphenols (Castillo, 1980), tannins (Chopra et al., 1969), and flavonols such as kaempferol and quercetin and their glycosides (Rao and Seshadri, 1969).

Madagascar is the chief supplier of pharmaceutical $C$. asiatica for the world market, with annual exports varying between 1979 and 1988 from 26 to $96 \mathrm{t} /$ year (Rasoanaivo, 1990). Plants are dried in the shade and powdered to make herbal capsules, which are sold in health food stores as herbal products. The powder of $C$. asiatica is greenish to greenish-brown in color. Under the microscope, fragments of lower and upper epidermis with characteristic stomata, palisade cells, rosette crystals of calcium oxalate, collenchyma, parenchyma cells, pitted and spiral vessels, and fibers can be seen (Bagchi and Puri, 1988).

\section{Medicinal uses}

Centella asiatica has been used for several centuries in folk medicine, and extracts were used as a drug in France in the late 1800s. Health claims range from enhanced memory and longevity to the treatment of leprosy (Kartnig, 1988; Turton, 1993). The perception of the plant as beneficial to general health may, likewise, be a contributing factor in its popularity as a vegetable in Sri Lanka.

Clinical tests and case studies have substantiated many of the positive benefits of $C$. asiatica extracts or asiaticoside in the healing of skin wounds (Kiesswetter, 1964), burns (Boiteau and Ratsimamanga, 1959; Gravel, 1965), and skin diseases (Bletry, 1980; Lythgoe and Trippett, 1949); in the treatment of stomach and duodenal ulcers (Ravokatra et al., 1974); and in the treatment of leprosy, lupus, scleroderma, and diseases of the veins (Anonymous, 1945a, 1945 b). Application can be external, oral, intramuscular, or subcutaneous, with doses depending on the formulation, malady treated, and the patient. Various products containing the extracts of the plant or asiaticoside are available for skin care in a number of countries today (e.g., Centasinum, Centelase, Dercut, Dercut Lotion, Ekzepiderm, Ekzevowen Salve, Elba-Dermazit, Elba-Dermidyn, Emdecassol, Lophakomp-Graphites, Madecassol, Psoriasia-Gastreu R 65) (Kartnig, 1988). Herbal capsules of $C$. asiatica can be found in health-food stores in the United States (e.g., GotuKola Herbal capsules; Solaray, Ogden, Utah). For a detailed critique of the medical studies with the plant, see Kartnig (1988).

The standardized extract and asiaticoside appear to have a very low level of toxicity via oral application (Lawrence, 1967). For example, a dose of asiaticoside as high as $1 \mathrm{~g} \cdot \mathrm{kg}^{-1}$ body weight of white rats was not toxic. Basedon these estimates, use of $C$. asiatica as a vegetable would not appear to pose a potential health risk. Exceeding this dosage would require a $68 \mathrm{~kg}$ (150 pound) man to consume more than $321 \mathrm{~kg}$ of fresh vegetable (about 23 bushels) per meal [assuming a terpenoid content of $0.1765 \%$ of the dryweight (Das and Mallick, 1991) and asiaticoside comprising $40 \%$ of the terpeniod fraction, $88 \% \mathrm{H}_{2} \mathrm{O}$ in fresh leaves, and 30-lb bushels].

\section{Conclusion}

The Asiatic pennywort may be a potential new specialty crop for the United States. It is a major leafy vegetable in Sri Lanka due to its unique flavor and nutritional and health attributes. Based on its current distribution as a wild plant in the southeastern United States and its general ease of culture, preliminary field and consumer acceptance tests in the United States may be worth considering.

\section{Literature Cited}

Anonymous. 1990. The crop recommendations technoquide. Dept. of Agr., Peradeniya, Sri Lanka.

Anonymous. 1978. Handbook for the Ceylon farmer. Ceylon Printers, Colombo, Sri Lanka.

Anonymous. 1945a. An advance on the treatment of leprosy. Lancet. Part 1. (1945):357.

Anonymous. 1945b. Treatment of leprosy. Nature 155:601

Bagchi, G.D. and H.S. Puri. 1988. Centella asiatica I. HerbaHungarica 27(2-3):137140

Bagchi, G.D. and H.S. Puri. 1989. Centella asiatica II. Herba Hungarica 28( 1-2): 127134.

Bautista, O.K., S. Kosiyachinda, A.S.A. Rahman and Soenoeadji. 1988. Traditional vegetables of ASIAN. ASIAN Food J. 4:47-58.

Bell, C.R. and L. Constance. 1960. Chromosome numbers in Umbelliferae II. Amer. J. Bot. 47:24-32.

Bhattacharyya, S.C. 1956a. Constituents of Centella asiatica. I. Examination of the Ceylonese variety. J. Ind. Chem. Soc. 33:597-586.

Bhattacharyya, S.C. 1956b. Constituents of Centella asiatica. III. Examination of the Indian variety. J. Ind. Chem. Soc. $33: 893-898$. 
Bhattacharyya, S.C. and B. Lythgoe. 1949. Derivatives of Centella asiatica used against leprosy. Triterpene acids. Nature. 163:259

Bletry, O. 1980. Comment on the treatment of scleroderma. Gaz. Med. Fr. 87:19891990.

Boiteau, P., A. Buzas, E. Lederer, and J. Polonsky. 1949. Derivatives of Centella asiatica used, against leprosy. Chemical constitution of asiaticoside. Nature 163:258

Boiteau, P. and A.R. Ratsimamanga. 1959. Important cicatrizants of vegetable origin and the biostimulins of Filatov. Bul. Soc. Sci. Bretagne 34:307-315.

Castillo, A.V., S.F. Castillo, and T.G. Mislang. 1980. A phytochemical study of Centella asiatica Linn. (fam. Umbelliferae). NRCP Res. Bul. 35:214-220.

Chopra, R.N., I.C. Chopra, and B.S. Varma. 1969. Glossary of Indian medicinal plants. Suppl. CSIR, New Delhi, India.

Chopra, R.N., S.L. Nayar, and I.C. Chopra. 1956. Glossary of Indian medicinal plants. CSIR, New Delhi, India.

Correll, D.S. and H.B. Correll. 1982. Flora of the Bahama Archipelago. J. Cramer, Vaduz.

Correll, D.S. and M.C. Johnston. 1970. Manual of the vascular plants of Texas. Texas Res. Found., Renner.

Cox D.N., S. Rajasuriya, P.E. Soysa, J. Gladwin, and A. Ashworth. 1993. Problems encountered in the community based production of leaf concentrate as a supplement for pre-school children in Sri Lanka. Intl. J. Food Sci. Nutr. 44:123-132.

Das, A. and R. Mallik. 1991. Correlation between genomic diversity and asiaticoside content in Centella asiatica (L.) Urban. Bot. Bul. Acad. Sinica 32:1-8.

George, V.K. and J.L. Gnanarethinam. 1975. A preliminary note on the free amino acids in Centella asiatica. Curr. Sci. 44(21):790.

Godfrey, R.K. and J.W. Wooten. 1981. Aquatic and wetland plants of the southeastern United States. Univ. of Georgia Press, Athens.

Gravel, J.A. 1965. Oxygen dressings and asiaticoside in the treatment of burns. Laval Med. 36:413-415.

Grieve, M. 1971. A Modern Herbal. The medicinal, culinary, cosmetic and economic properties, cultivation and folk-lore of herbs. Dover Publications, London.

Gunasekera, G.G.S. and G. Ravindran. 1989. Antinutritional properties and vitamin C content of green leafy vegetables and their losses during home level preparations. Trop. Agr. Res. 1:191-201.

Jayaweera, D.M.A. 1982. Medicinal plants used in Ceylon. Nat. Sci. Coun. Sri Lanka 5:134-135.

Joshi, S. and S.S. Raghuvanshi. 1970. Bchromosomes in Centella asiatica. Genetics Ibertica 22:161.

Kailasapathy, K. and T. Koneshan. 1986. Effect of wilting on the ascorbate content of selected fresh green leafy vegetables consumed in Sri Lanka. J. Agr. Food Chem. 34:259-261.

Karrer, W., H. Hurlimann, and E. Cherbuliez. 1985. Constitution und vorkommen der organischen pflanzenstoffe (exclusive alkaloid). Erganzungsband 2, Teil 2. Birkhauser Verlag, Basel.

Kartnig, T., F. Bucar, H. Charzewski, and R. Melcher. 1987. Concerning the identification of plant drugs newly incorporated into the 1981 Austrian medical practice. Scientia Pharm. 55:147-158.

Kartnig, T. 1988. Clinical applications of Centella asiatica (L.) Urb in herbs, spices and medicinal plants. In: L.E. Cracker and J.E. Simon (eds.). Recent advances in botany, horticulture and pharmacology. Vol. 3.

Kays, S.J. and J.C.S. Dias. 1995. Common names of commercially cultivated vegetables of the world in 15 languages. Econ. Bot. 49:115-152.

Kiesswetter, H. 1964. Erfahrungsbericht ber behandlung von wunden mit asisticosids (madecassol). Wien Med. Wschr. 114:124126.

Kishun, R. and R. Chand. 1988. Epiphytic survival of Xanthomonas campestris pv. campestris on Centella asiatica (L) Urban. Intl. J. Trop. Plant Dis. 6:189-193.

Lawrence, J.C. 1967. The morphological and pharmacological effects of asiaticoside upon skin in vitro and in vivo. Europ. J. Pharmacol. 1:414-424.

Lesley, B. 1994. Herbs. Dorling Kinderley, London.

Lythgoe, B. and S. Trippett. 1949. Derivatives of Centella asiatica used against leprosy. Centelloside. Nature 163:259-260

Mabberley, D.J. 1987 The plant-book. Cambridge Univ. Press, Cambridge.

Malhotra, C.L., P.K. Das, M.S. Sastry, and N.S. Dhalla. 1961. Chemical and pharmacological studies in Hydrocotyle asiatica. Ind. J. Pharmacol. 23:106-107.

Mandal, N.R. 1992. Notes on some interesting plants from Sikkim. J. Econ. Tax. Bot. 16:234-236.

Rahandraha, T., M. Chanez, and P. Boiteau. 1963a. Determination of the anthrone asiaticoside and oside ester in Centella asiatica. Ann. Pharm. Fr. 21(4):313-320.

Rahandraha, T., M. Chanez, P. Boiteau, and S. Jaquard. 1963b. Determination of asiaticoside isolated from Hydrocotyl asiatica by anthrone and quantitative thin layer chromatography on powdered glass. Ann. Pharm. Fr. 21:561-567.

Rao, P.S. and T.R. Seshadri. 1969. Variation in the chemical composition of Indian samples of Centella asiatica. Curr. Sci. 38:77-79.

Ravokatra, A., A. Loiseau, S. Ratsimamanga-Urverg, M. NigeonDureuil, and A.R. Ratsimamanga. 1974. Action de l'asiaticoside (tritrpene pentacyclique) retir de l'Hydrocotyle Madagascariensis sur les ulcres duodnaux crs par la mercaptothylamine chez le rat Wistar mle. C.R Acad. Sci Paris 278:23172321.

Rosoanaivo, P. 1990. Rain forests of Madagascar: Sources of industrial and medicinal plants. Ambio 19:421-424.

Sharma, A.K. and C. Ghosh. 1954. Cytogenetics of some of the Indian umbellifers. Genetics 27:17-44.

Singh, B. and R.P. Rastogi. 1968. Chemical examination of Centella asiatica. III. Constitution of brahmic acid. Photochemistry 7:1385-1393.

Singha, B.M.B. and A.K. Singha. 1977. Meiotic studies in some species of Umbelliferae. Cytologia 42:465-471.

Subramanian, D. 1986. Cytotaxonomical studies in south Indian Apiaceae. Cytologia 51:479-488

Turton, S. 1993. Centella asiatica. Austral. J. Med. Herbal. 5(3)57-61.

Wali, M.A. and M.C. Tummin Katti. 1937. Chemical examination of the constituents of Hydrocotyle asiatica. Part I. Proc. Ind. Acad. Sci. V. Sect. A:109-114.

Wankahar, B. and R.S. Tripathi. 1990a. Growth and reproductive allocation pattern of Centella asiatica raised from stem cuttings of different sizes in relation to light regimes, soil texture and soil moisture. Acta Ecologica 5:683-692.

Wankahar, B. and R.S. Tripathi. $1990 b$. Competitive fitness of Centella asiatica populations raised from stem cuttings and seedlings. Proc. Ind. Acad. Sci. (Plant Sci.) 100:239-245

Wankahar, B. and R.S. Tripathi. 1993. Population dynamics of Centella asiatica (Linn.) Urb., A clonal herbaceous perennial in 'Jhum' fallows. Trop. Ecol. 34:35-43.

Zanariah, J., A.N. Rehan, and O. Rosnah. 1986. Protein and amino acid composition of Malaysian vegetables. MARDI Res. Bul. 14:140-147.

Zoysa, I.J. De and H.T.K. Liyanage. 1994. Bacterial wilt of Centella asiatica in Sri Lanka. Bact. Wilt Nwsltr 10:5. 